\title{
Thoracic surgery without borders: an Italian-German meeting
}

The Department of Vascular and Thoracic Surgery directed by Reinhold Perkmann organizes every 2 years an international conference on current issues of Thoracic Surgery at the Regional Hospital of Bolzano. This international meeting is called BIC (Bolzano International Conference). The motto of the 2019 edition "Thoracic surgery without frontiers" not only expresses that expert speakers from some of the most important centers of Italy, Germany and Austria meet in Bolzano, but also underlines that thoracic surgery in recent years has crossed unimaginable borders and it is no longer limited to traditional methods and techniques but manages to go much further. The technical-technological surgical and anesthesiologic evolutions allow today an extension of the open and video-assisted thoracic surgery procedures. Furthermore, the new frontiers of target therapy and immunotherapy are revolutionizing the indications for surgery for non-small cell lung cancer.

Topics to be addressed in this special series will include these currently unclear controversies, from the treatment of the chest wall and mediastinal diseases to surgery of the trachea and non-small cell lung cancers, both thoracoscopically and traditionally.

We warmly thank not only all the colleagues but also the editorial board who contributed to the drafting of the conference proceedings. The effort made has allowed the creation of a collection of experiences of high scientific profile, which represents the scientific reality of some of the best Italian, German and Austrian thoracic surgery centers.

\section{Acknowledgments}

Funding: None.

\section{Footnote}

Provenance and Peer Review: This article was commissioned by the editorial office, Current Challenges in Thoracic Surgery for the special series "Thoracic Surgery Without Borders". The article did not undergo external peer review.

Conflicts of Interest: All authors have completed the ICMJE uniform disclosure form (available at https://ccts.amegroups.com/ article/view/10.21037/ccts.2020.03.04/coif). The special series "Thoracic Surgery Without Borders" was commissioned by the editorial office without any funding or sponsorship. FZ, LB, RP and RC served as unpaid Guest Editors of the special series. The authors have no other conflicts of interest to declare.

Ethical Statement: The authors are accountable for all aspects of the work in ensuring that questions related to the accuracy or integrity of any part of the work are appropriately investigated and resolved.

Open Access Statement: This is an Open Access article distributed in accordance with the Creative Commons AttributionNonCommercial-NoDerivs 4.0 International License (CC BY-NC-ND 4.0), which permits the non-commercial replication and distribution of the article with the strict proviso that no changes or edits are made and the original work is properly cited (including links to both the formal publication through the relevant DOI and the license). See: https://creativecommons.org/licenses/by-nc$\mathrm{nd} / 4.0 \%$. 


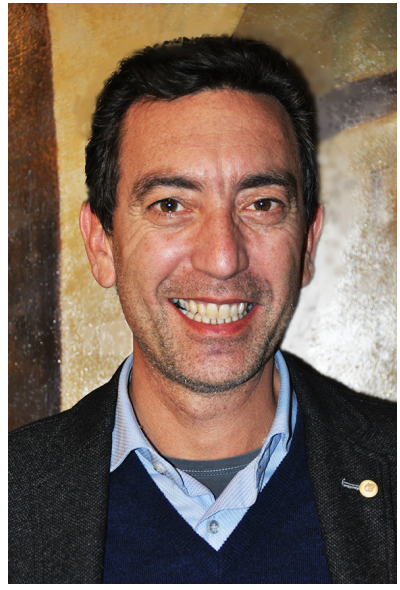

Francesco Zaraca

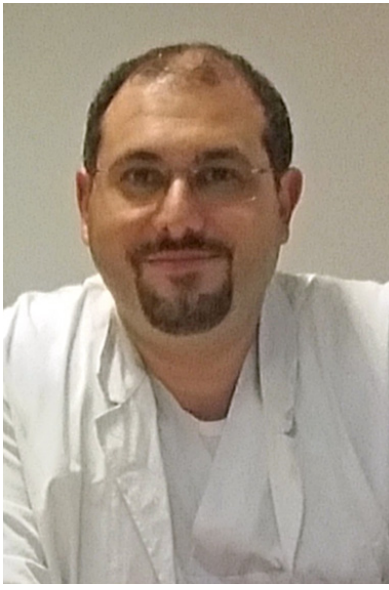

Luca Bertolaccini

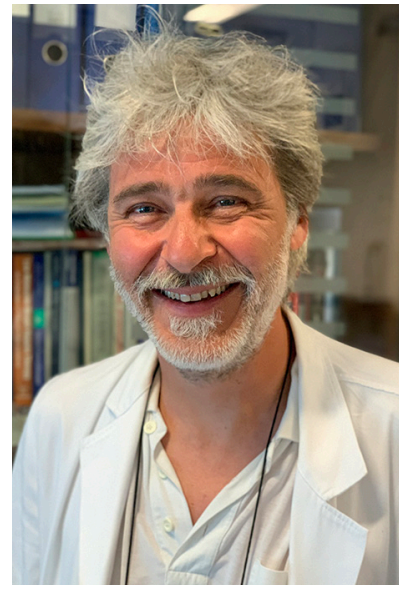

Reinhold Perkmann

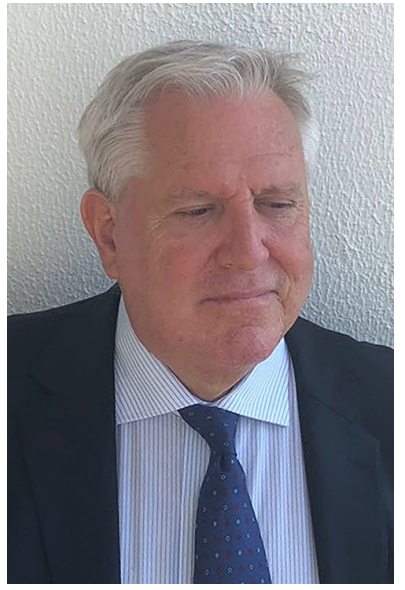

Roberto Crisci

Francesco Zaraca, $\mathrm{MD}, \mathbf{P h D}^{1}$ (Email: francesco.zaraca@sabes.it) Luca Bertolaccini, $\mathrm{MD}, \mathrm{PhD}, \mathrm{FCCP}^{2}$

(Email: luca.bertolaccini@gmail.com) Reinhold Perkmann, $\mathbf{M D}^{1}$

(Email: reinhold.perkmann@sabes.it) Roberto Crisci, MD, Full Professor of Thoracic Surgery ${ }^{3}$ (Email: crisciroberto@gmail.com)

${ }^{1}$ Division of Vascular and Thoracic Surgery, Hospital of Bolzano, Bolzano, Italy; ${ }^{2}$ Division of Thoracic Surgery, IEO European Institute of Oncology IRCCS, Milan, Italy; ${ }^{3}$ Division of Thoracic Surgery, Thoracic Surgery Unit, University of L'Aquila, "G. Mazzini" Hospital, Teramo, Italy. Received: 21 February 2020; Accepted: 16 March 2020; Published: 25 August 2020. doi: $10.21037 /$ ccts.2020.03.04

View this article at: http://dx.doi.org/10.21037/ccts.2020.03.04

doi: $10.21037 /$ ccts.2020.03.04

Cite this article as: Zaraca F, Bertolaccini L, Perkmann R, Crisci R. Thoracic surgery without borders: an Italian-German meeting. Curr Chall Thorac Surg 2020;2:22. 